\title{
INTELECTUAL CAPITAL, MARKET CAP DAN PENGARUHNYA TERHADAP PERTUMBUHAN KEUANGAN PERUSAHAAN NON- KEUANGAN YANG TERDAFTAR DI BEI PERIODE 2016-2019
}

\author{
Andini Nurwulandari \\ Universitas Nasional, Jakarta \\ Email: andinmanajemen@gmail.com
}

\begin{abstract}
Abstrak
Mengukur aset data melibatkan penilaian, pengembangan, pelacakan dan pengelolaan berbagai variabel tak berwujud, maka ha ini semakin penting untuk kinerja bisnis. Tujuan dari analisis ini adalah untuk menguji dampak output keuangan dari intellectual capital dan market cap. Penelitian ini menggunakan metode kuantitatif dengan pendekatan analisis deskriptif. Data penelitian diambil dari total 9 perusahaan yang menjadi data penelitian tahun 2016-2019 untuk digunakan oleh perusahaan non-keuangan yang terdaftar di pasar saham Indonesia; Proses studi adalah analisis data panel. Temuan dari penelitian ini menunjukkan bahwa VACA, VAIC, Market Capital Value Added (MCVA) dan Earnings per Share memiliki pengaruh yang menguntungkan (ROE). Dari penelitian ini diketahui bahwa Market Cap dan Intellectual Capital memiliki pengaruh yang positif terhadap pengembalian ekuitas (ROE).
\end{abstract}

Kata Kunci: Value Added Capital Employed (VACA), Value Added Intellectual Capital (VAIC), Market Capital Value Added (MCVA), Return On Equity (ROE).

\begin{abstract}
Although measuring data assets involves assessing, development, tracking and managing a variety of intangible variables, they are progressively essential for business performance. The goal of the analysis is to examine the impact on financial output of intellectual capital and market cap. The writer utilizes research data from a total of 9 firms in the study data for 2016-2019 to be used by non-financial listed companies on the Indonesian stock market; the study process is the analysis of panel data. The findings from this study indicated that VACA, VAIC, Market Capital Value Added (MCVA) and Earnings per Share had a favorable and meaningful effect (ROE). Sustainability reporting, however, has little effect on equity returns $(R O E)$.
\end{abstract}

Keywords: Value Added Capital Employed (VACA), Value Added Intellectual Capital (VAIC), Market Capital Value Added (MCVA), Return On Equity (ROE).

\section{A. PENDAHULUAN}

Penilaian tradisional atas kinerja ekonomi nasional bergantung pada pemahaman PDB dalam kaitannya dengan faktor-faktor tradisional produksi, seperti tanah, tenaga kerja dan modal (Dzenopoljac \& Bontis, 2017). Aset pengetahuan dapat dibedakan dari faktor-faktor produksi tradisional di mana mereka diatur oleh yang telah dijelaskan sebagai "hukum keuntungan yang meningkat" (Alviane, 2011). Berbeda dengan faktor-faktor produksi tradisional yang diatur oleh hasil yang semakin berkurang, setiap unit tambahan pengetahuan 
yang digunakan secara efektif menghasilkan peningkatan marjinal dalam kinerja (Amruah, 2019). Keberhasilan perusahaan seperti Microsoft sering dikaitkan dengan fakta bahwa setiap unit tambahan dari produk atau layanan berbasis informasi akan menghasilkan peningkatan keuntungan marjinal (Corrêa, 2019). Mengingat dinamika perubahan yang mendasari kinerja nasional, tidak mengherankan bahwa beberapa negara kurang berkembang dengan aset signifikan dalam pengetahuan TIK dan keahlian terkait Internet berharap untuk melompati ekonomi yang lebih maju (Abuaoush, 2018).

Meskipun peran aset berbasis pengetahuan semakin penting dalam kinerja nasional, sebagian besar negara masih menilai kinerja mereka berdasarkan faktor produksi tradisional (Edvinsson, 1997). Sistem pengukuran saat ini terbatas dalam kemampuannya untuk memperhitungkan pengetahuan diam-diam yang tertanam dalam sumber daya manusia, meskipun ada beberapa kesepakatan tentang pengukuran beberapa kategori aset terkait pengetahuan, seperti paten dan merek dagang. Namun, ekonomi pengetahuan yang muncul dicirikan oleh industri yang lebih intensif pengetahuan dan ekonomi jasa yang semakin didasarkan pada aset tidak berwujud berbasis informasi (Indriyani, 2017). Aset pengetahuan atau modal intelektual dapat digambarkan sebagai aset "tersembunyi" dari suatu negara yang menopang pertumbuhannya, mendorong pertumbuhannya, dan mendorong nilai pemangku kepentingan (Herli \& Hafidhah, 2018). Terdapat peningkatan kesadaran tentang manajemen pengetahuan sebagai pendorong utama kekayaan nasional, penggerak inovasi dan pembelajaran, serta produk domestik bruto (PDB) negara. Semakin pentingnya aset pengetahuan dan modal intelektual telah menarik perhatian yang lebih besar tidak hanya dari CEO perusahaan, tetapi juga pembuat kebijakan nasional, terhadap indikator pertumbuhan dan kinerja non-keuangan di masa depan (Hanafi, 2020).

Pengukuran aset pengetahuan berkaitan dengan penilaian, pertumbuhan, pemantauan, dan pengelolaan dari sejumlah faktor tak berwujud tetapi semakin penting dalam kesuksesan bisnis (Mashai, 2018). Dalam konteks aset pengetahuan, pengetahuan merepresentasikan tubuh kolektif aset tak berwujud yang dapat diidentifikasi dan diukur (Obeidat \& Aqqad, 2017). Interpretasi pengetahuan ini berbeda dari pengertian pengetahuan sebagai pengetahuan dan pembelajaran, yang menyangkut bagaimana organisasi memperoleh, berbagi, dan menggunakan pengetahuan, baik dibantu atau dihalangi oleh teknologi dan proses organisasi (Kianto, 2017). Sebaliknya, pengertian aset pengetahuan adalah tentang aspek-aspek yang dapat diidentifikasi dari organisasi yang meskipun "tidak berwujud," dapat dianggap menambahkan beberapa jenis nilai padanya (Nurcahono \& Astutik, 2018). Contoh aset pengetahuan tersebut dapat mencakup pola dan layanan pengetahuan bersama serta kemampuan pelanggan (Kamela, 2021).

Dalam konteks aset pengetahuan, pengetahuan merepresentasikan tubuh kolektif aset tak berwujud yang dapat diidentifikasi dan diukur (Sardo \& Alves, 2018). Interpretasi pengetahuan ini berbeda dari pengertian pengetahuan sebagai pengetahuan dan pembelajaran, yang menyangkut bagaimana organisasi memperoleh, berbagi, dan menggunakan pengetahuan, baik dibantu atau dihalangi oleh teknologi dan proses organisasi (Rajinda, 2018). Sebaliknya, pengertian aset pengetahuan adalah tentang aspek-aspek yang dapat diidentifikasi dari organisasi yang meskipun "tidak berwujud," dapat dianggap menambahkan beberapa jenis nilai padanya (Sari, 2019). "Modal pengetahuan" (Seth \& Sharma, 2019). Contoh aset pengetahuan tersebut dapat mencakup pola dan layanan pengetahuan bersama 
ARTIKEL

serta kemampuan pelanggan (Smriti \& Das, 2018).

Berikut merupakan data peringkat dalam mengukur intellectual capital di berbagai Negara yang diperoleh dari GSCI (Global Sustainable Competitiveness Index):

Tabel 1 Peringkat Intellectual Capital Tahun 2019

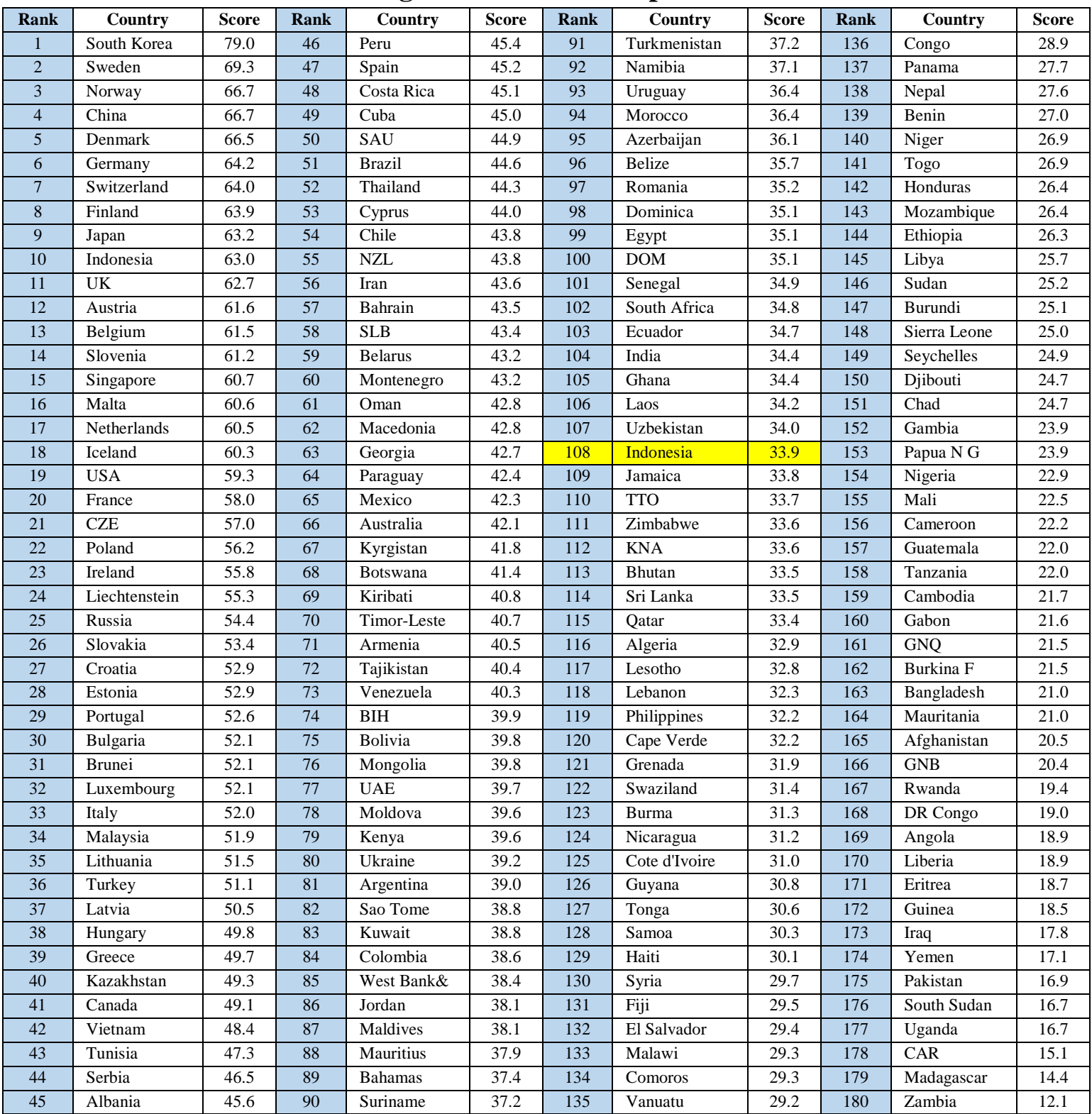

Sumber: Data diolah

Dalam data GSCI (Global Sustainable Competitiveness Index) di atas, Indonesia menduduki peringkat 108 dengan skor 33,9 pada tahun 2017. Dimana peringkat tersebut terpaut jauh dengan Negara tetangga seperti Singapura yang menduduki peringkat 15 dengan skor 60,7 atau Malaysia yang menduduki peringkat 34 dengan skor 51,9.

Market cap mencerminkan modal intelektual yang tertanam dalam hubungan Indonesia dengan negara lain. Aset intelektual di bidang ini berasal dari kemampuan dan keberhasilan suatu negara dalam memberikan solusi yang menarik dan kompetitif untuk kebutuhan klien internasional. Investasi dan pencapaian Indonesia dalam hubungan luar negeri, bersama dengan ekspor produk dan layanan berkualitasnya secara signifikan berkontribusi pada aset tidak berwujud yang membentuk market cap dikarenakan modal 
proses suatu perusahaan. Indikator modal pasar termasuk pariwisata keluar, keterbukaan terhadap budaya asing, dan acara internasional dan keterampilan bahasa. Kemampuan inti tersebut menciptakan dasar untuk menilai daya tarik negara dari perspektif klien internasional (Suwardika \& Mustanda, 2017). Memberikan Solusi untuk Kebutuhan Pasar: Dengan lingkungan bisnis yang dinamis yang ditandai dengan perubahan kebutuhan pelanggan, kapabilitas suatu negara dalam memenuhi kebutuhan tersebut mewakili keunggulan kompetitif di pasar global. Indonesia menempati peringkat di antara negara-negara teratas yang dianggap memiliki waktu tercepat untuk memperkenalkan produk dan layanan baru serta mereka penetrasi di pasar (Tulung, 2018).

Tingkat partisipasi negara dalam acara internasional merupakan indikator dari keinginan kuat untuk pembaruan serta keterbukaan dan kemauan untuk mendapatkan pengetahuan. Mengingat tingkat partisipasinya yang tinggi, Indonesia dipandang memiliki motivasi yang luar biasa untuk membuka diri ke front intelektual baru. Selain itu, tingginya tingkat penyelenggaraan konferensi internasional di Indonesia merupakan indikator daya tarik Indonesia bagi para pebisnis dari seluruh dunia. Indikator ini mencerminkan tingkat keterbukaan internasional Indonesia dan meningkatnya minat entitas internasional di Indonesia. Keterbukaan terhadap Budaya yang Berbeda: Keinginan orang untuk bertemu dengan orang lain, belajar, melihat, memperluas wawasan mereka, dan mengembangkan serta memperbarui diri dapat dianggap sebagai indikator lain dari modal pasarnya. Keterbukaan warga Indonesia terhadap budaya yang berbeda merupakan saluran komunikasi yang penting dalam mempelajari tren dan kebutuhan di dusun global (Utomo, 2018).

Komponen ini mewakili aset intelektual negara (termasuk perusahaan) yang mendukung aktivitasnya saat ini, termasuk berbagi, pertukaran, aliran, pertumbuhan, dan transformasi pengetahuan dari modal manusia menjadi modal struktural. Market cap tersebut termasuk sistem informasi, laboratorium, teknologi, perhatian manajemen, dan prosedur. Pertumbuhan jangka panjang suatu negara dapat dicapai jika sumber daya manusia diintegrasikan dalam sistem struktural yang ada. Integrasi tersebut melalui sistem informasi dan komunikasi meningkatkan kemampuan bangsa untuk mengantisipasi dan menerjemahkan kebutuhan pasar ke dalam aplikasi produk dan layanan. Teknologi informasi berfungsi sebagai alat utama untuk menghasilkan produk dan layanan berkualitas tinggi dan membuka saluran akses ke pasar baru. Indikator modal proses meliputi komunikasi dan komputerisasi, pendidikan, pertanian, manajemen, ketenagakerjaan, pengembangan sektor jasa, dan penyerapan imigran.

1. Luas Penggunaan Internet: Penggunaan internet memungkinkan untuk berbagi informasi dengan cepat dan untuk berkomunikasi serta berkolaborasi bahkan ketika terisolasi oleh geografi dan zona waktu. Laporan tersebut menegaskan bahwa tingkat penggunaan Internet juga merupakan indikator penting untuk penilaian manajemen pengetahuan yang efektif di suatu negara. Sebuah indeks yang mengukur tingkat penggunaan Internet relatif terhadap ukuran populasi menempatkan Indonesia di peringkat tinggi dalam daftar negara maju.

2. Sirkulasi Surat Kabar Harian: Distribusi surat kabar per kapita diasumsikan sebagai indikator lain dari tingkat berbagi pengetahuan dan keterlibatan dalam kejadiankejadian di seluruh dunia. Menurut laporan Bank Dunia, Indonesia menempati urutan tinggi dalam daftar negara dengan distribusi surat kabar perkapita tertinggi. 
3. Tingkat Penggunaan Perangkat Lunak: Tingkat penggunaan perangkat lunak mencerminkan tingkat berbagi pengetahuan dan upaya untuk mengubah modal manusia menjadi modal struktural. Tingkat penggunaan perangkat lunak juga berfungsi sebagai indikator kualitas infrastruktur negara saat ini yang mendukung pengelolaan informasi dan pengetahuan yang efektif. Sebuah indeks yang didasarkan pada hubungan antara tingkat pengeluaran untuk perangkat keras dan tingkat pengeluaran untuk perangkat lunak menempatkan Indonesia di antara peringkat teratas negara-negara maju.

4. Pendidikan: Pendidikan meningkatkan berbagi dan membangun pengetahuan dan asimilasi mekanisme aliran pengetahuan di masyarakat. Tiga indikator yang digunakan untuk menilai investasi Indonesia dalam pendidikan termasuk rasio siswaguru, rasio PC-siswa, dan kebebasan berekspresi dalam sistem sekolah. Berdasarkan data yang tersedia dan survei nasional, Indonesia menempati peringkat tinggi dalam semua kriteria penilaian ini.

\section{B. METODE}

Penelitian ini menggunakan jenis penelitian kuantitatif dengan pendekatan analisisdeskriptif. Jenis data yang digunakan adalah data sekunder. Populasi penelitian ini adalah perusahaan non-keuangan yang tercatat di BEI periode 2016-2019 yang berjumlah sebanyak 465 perusahaan. Sedangkan dokumentasi menjadi menjadi metode pengumpulan data.

Tabel 2 Jumlah Sampel Perusahaan Non-Keuangan

\begin{tabular}{|c|l|c|}
\hline No. & \multicolumn{1}{|c|}{ Kriteria } & Jumlah \\
\hline 1 & Perusahaan Non-Profit yang tercatat di BEI pada tahun 2016-2019 & 465 \\
\hline 2 & Perusahaan Non-Profit yang tidak pernah delisting pada tahun 2016-2019 & 442 \\
\hline 3 & $\begin{array}{l}\text { Perusahaan yang menerbitkan laporan tahunan dan sustainability report } \\
\text { dengan indeks GRI-G4 periode 2016-2019 }\end{array}$ & 10 \\
\hline \multicolumn{2}{|c|}{ Jumlah Sampel } & $\mathbf{1 0}$ \\
\hline
\end{tabular}

Sumber: Data diolah

\section{HASIL DAN PEMBAHASAN}

Statistik deskriptif variabel yang diamati yaitu ROE (Y), Value Added Capital Employed (X1), Value Added Intellectual Capital (X2), dan Market Cap Value Added (X3). Data disajikan dalam tabel berikut ini:

\section{Tabel 3 Statistik Data Penelitian}

\begin{tabular}{|l|c|c|c|c|}
\hline & ROE & VACA & VAIU & MCVA \\
\hline Mean & 8.321323 & 0.2345562 & 3.546455 & 4.2134212 \\
\hline Median & 11.93212 & 0.183222 & 2.571231 & 0.572420 \\
\hline Maximum & 33.25310 & 0.722331 & 8.8851200 & 82.23132 \\
\hline Minimum & -31.23460 & -0.522340 & -3.727111 & -3.212101 \\
\hline Std. Dev. & 16.10575 & 0.323402 & 3.417404 & 15.82127 \\
\hline Skewness & -2.124436 & -0.325233 & 0.482894 & 5.232123 \\
\hline Kurtosis & 5.552425 & 5.833820 & 3.723410 & 18.87824 \\
\hline Jarque-Bera & 11.23452 & 12.23452 & 0.873321 & 529.4936 \\
\hline Probability & 0.101252 & 0.111136 & 0.522662 & 0.11112 \\
\hline Sum & 123.7432 & 5.32120 & 75.67322 & 151.2311 \\
\hline Sum Sq. Dev. & 8744.125 & 1.950353 & 330.1251 & 9332.995 \\
\hline Observations & 35 & 35 & 35 & 9 \\
\hline Cross sections & 9 & 9 & 9 & 9 \\
\hline
\end{tabular}

Sumber: Output E-views 9 


\section{Return on Equity (ROE)}

Minimum value ROE sebesar -31.23460 sedangkan nilai maksimum adalah 33.25310. Nilai rata-rata bagi hasilnya adalah 8.321323 dengan deviasi yaitu 16.10575 .

\section{Value Added Capital Employed (VACA)}

Data hasil penelitian menunjukkan bahwa selama periode penelitian ini menunjukkan minimum value VACA sebesar -0.522340 sedangkan maximum value adalah 0.722331 . Mean value bagi hasilnya sebesar 0.2345562 dengan deviation standard yaitu 0.323402 .

\section{Value Added Intellectual Capital (VAIU)}

Data hasil penelitian menunjukkan bahwa selama periode penelitian ini menunjukkan nilai minimum VAIU sebesar -3.727111 sedangkan maximum value sebesar 8.8851200 . Mean value bagi hasilnya adalah 3.546455 dengan deviation standard yaitu 3.417404

\section{Market Cap Value Added (MCVA)}

Data hasil penelitian menunjukkan bahwa selama periode penelitian ini menunjukkan nilai minimum MCVA sebesar -3.212101 sedangkan maximum value sebesar 82.23132. Mean value bagi hasilnya sebesar 4.2134212 dengan deviation standard yaitu 15.82127 .

\section{Metode Common Effect}

Model ini menggabungkan data deret waktu dengan penampang melintang saja. Untuk setiap dimensi penampang, pendekatan ini berarti perkiraan nilai $\alpha$ yang konstan. Sistem ini akan menggunakan OLS. Regresi dengan pengaruh populer adalah sebagai berikut:

\section{Tabel 4 Model Common Effect}

Dependent Variable: ROE?

Method: Pooled Least Squares

Date: 02/08/19 Time: 23:38

Sample: 20142017

Included observations: 4

Cross-sections included: 9

Total pool (balanced) observations: 36

\begin{tabular}{ccccr}
\hline \hline & & & \\
Variable & Coefficient & Std. Error & t-Statistic & Prob. \\
\hline VACA? & -1.897469 & 4.582312 & -0.414522 & 0.6344 \\
VAIU? & 34.04177 & 14.86225 & 2.292348 & 0.0459 \\
MCVA? & -0.236607 & 1.393767 & -0.169972 & 0.8450 \\
& -0.027805 & 0.163657 & -0.123121 & 0.8344 \\
\hline \hline & & & \\
R-squared & 0.260752 & Mean dependent var & \\
Adjusted R-squared & 0.165434 & S.D. dependent var & \\
S.E. of regression & 13.88406 & Akaike info criterion & & 15.07696 \\
Sum squared resid & 5881.443 & Schwarz criterion & 8.211687 \\
Log likelihood & -142.8067 & Hannan-Quinn criter. & 8.431640 \\
F-statistic & 2.733483 & Durbin-Watson stat & 8.288470 \\
Prob(F-statistic) & 0.046643 & & 0.742222 \\
\hline \hline
\end{tabular}

Sumber: Hasil Output Eviews 9 
Diperoleh persamaan sebagai berikut: $\mathrm{ROE}=-1.897+34.041$ VACA - 0.236 VAIU 0.0278 MCVA. Konsekuensi dari persamaan ini adalah -1,898, dan output keuangannya kemudian konstan adalah -1,898, yang merupakan konstanta. Hasil Value Added Capital Employed (VACA) memperkirakan bahwa nilai perusahaan non keuangan akan meningkat sebesar 34.041. Koefisien VACA meningkat sebesar 1\%. Hal ini berpengaruh positif besar terhadap valuasi ROE dengan peluang $0,0459<0,05$. Menurut perkiraan, VAIU memiliki koefisien yang dapat disesuaikan secara negatif sebesar -0,236. Artinya, pentingnya output keuangan pada perusahaan non-keuangan berkurang -0,236 jika VAHU dinaikkan sebesar 1 persen. VAIU tidak berdampak negatif dengan nilai ROE dengan likelihood 0.8450>0.05.

Berdasarkan estimasi, Market Cap Intellectual Capital (MCVA) berpengaruh negatif sebesar -0.0278 yang berarti jika MTVA meningkat sebesar 1\% maka nilai pada perusahaan non keuangan akan turun menjadi -0.0278. Artinya MTVA memiliki pengaruh yang kecil terhadap nilai ROE dengan probabilitas 0,8344 > 0,05.

\section{Metode Fixed Effect}

Berikut merupakan hasil dari regresi menggunakan Fixed Effect:

Tabel 5 Model Fixed Effect

\begin{tabular}{crrrr}
\hline \hline Variable & Coefficient & Std. Error & t-Statistic & Prob. \\
\hline C & -4.614317 & 4.276686 & -1.719290 & 0.0990 \\
VACA? & 33.20502 & 12.67855 & 2.642738 & 0.0145 \\
VAIU? & 4.282126 & 0.951691 & 2.817181 & 0.0098 \\
MCVA? & 0.199575 & 0.088966 & 2.243272 & 0.0348 \\
Fixed Effects (Cross) & & & & \\
_AALI--C & 0.785855 & & \\
_EXCL--C & -32.88500 & & \\
_GIAA--C & -4.569234 & & \\
_INDY--C & 0.602606 & & \\
_JSMR--C & 2.880011 & & \\
-PTBA--C & 18.89713 & & 7.073463 \\
-PTRO--C & -4.078903 & & \\
-TOTL--C & 15.84025 & & \\
-UNTR--C & 2.527293 & & \\
\hline \hline
\end{tabular}

Sumber: Hasil Output Eviews 
Berdasarkan data di tabel di atas, dapat diperoleh persamaan sebagai berikut: ROE = 4,614 + 33,205 VACA + 2,681VAHU + 0,199MTVA . Dari hasil persamaan tersebut, nilai konstanta sebesar -5,634, konstan maka nilai kinerja keuangan sebesar -4,614.

Berdasarkan data tersebut maka model Fixed Effect dinyatakan dalam persamaan dengan rata-rata koefisien terbesar dimiliki oleh perusahaan Bukit Asam (PTBA) sebagai berikut: $\mathrm{ROE}=18,897-5,634+33,506 \mathrm{VACA}+2,681 \mathrm{VAHU}+0,199 M T V A$. Artinya, apabila Value Added Capital Employed (VACA), Value Added Intellectual Capital (VAIU), dan Process Capital Value Added (PTVA) dianggap konstan, maka nilai ROE pada perusahaan Bukit Asam sebesar 13,263.

Persamaan dengan rata-rata koefisien terkecil dimiliki oleh perusahaan XL Axiata (EXCL) sebagai berikut: ROE $=-32,885-5,634+33,506 \mathrm{VACA}+2,681 \mathrm{VAHU}+0,199 \mathrm{MTVA}-$ 0,289ENVD. Artinya, Market Cap Value Added (MCVA), dianggap konstan, maka nilai ROE pada perusahaan XL Axiata sebesar -38,519.

VACA berpengaruh positif sebesar 33,205, artinya jika VACA naik $1 \%$ maka nilai kinerja keuangan pada perusahaan non-keuangan akan naik sebesar 33,205, Probabilitas mencapai angka $0,0145<0,05$, dan VACA berefek positif, Artinya, apabila nilai Value Added Capital Employed mengalami kenaikan maka akan meningkatkan nilai ROE, Sebaliknya, apabila Value Added Capital Employed mengalami penurunan maka akan menurunkan nilai ROE.

Variabel Value Added Intellectual Capital (VAIU) memiliki koefisien bernilai positif sebesar 4,282, artinya jika VAHU naik 1\% maka nilai kinerja keuangan pada perusahaan non-keuangan akan naik sebesar 4,282, Dengan nilai probibility 0,0098<0,05, VAIU berdampak positif, Artinya, apabila nilai Value Added Intellectual Capital mengalami kenaikan maka akan meningkatkan nilai ROE, Sebaliknya, apabila Value Added Intellectual Capital mengalami penurunan maka akan menurunkan nilai ROE.

Variabel Market Cap Value Added (MCVA) adalah 0,199, artinya jika VAHU naik $1 \%$ maka nilai kinerja keuangan pada perusahaan non-keuangan akan naik sebesar 0,199, Dengan probability adalah 0,0348<0,05, Artinya, apabila nilai Process Capital Value Added mengalami kenaikan maka akan meningkatkan nilai ROE, Sebaliknya, apabila Process Capital Value Added mengalami penurunan maka akan menurunkan nilai ROE.

\section{KESIMIPULAN}

Berdasarkan rumusan masalah dan hasil pembahasan, maka dapat diambil kesimoulan sebagai berikut: 1) Value Added Capital Employed (VACA) memiliki pengaruh yang positif signifikan terhadap kinerja keuangan (ROE); 2) Value Added Intelectual Capital (VAIU) memiliki pengaruh yang positif signifikan terhadap kinerja keuangan (ROE), Hal ini menjelaskan, apabila nilai Value Added Intellectual Capital mengalami kenaikan maka akan meningkatkan nilai ROE; 3) Market Cap Value Added (MCVA) memiliki pengaruh yang positif signifikan terhadap kinerja keuangan (ROE), Hal ini menjelaskan, apabila nilai Process Capital Value Added mengalami kenaikan maka akan meningkatkan nilai ROE. 


\section{DAFTAR PUSTAKA}

Abualoush, S, Masa'deh, R, Bataineh, K,, \& Alrowwad, A, (2018), The role of knowledge management process and intellectual capital as intermediary variables between knowledge management infrastructure and organization performance, Interdisciplinary Journal of Information, Knowledge, and Management, 13, 279-309,

Alviane, G, (2011), Pengaruh Intellectual Capital Terhadap Kinerja Perusahaan: Perspektif Balanced Scorecard, Jurnal Akuntansi Bisnis, 9(18), 175-192,

Amrullah, R,, Ismail, T,, \& Uzliawati, L, (2019), Pengaruh Budaya Organisasi, Intellectual Capital Dan Keragaman Pengukuran Kinerjan Terhadap Kinerja Organisasi (Study Empiris Perusahaan Manufaktur Di Provinsi Banten), Jurnal Riset Akuntansi Tirtayasa, 3(2), 221-240,

Corrêa, A, B, N, Marçal, R, R, \& Flach, L, (2019), Previsibilidade No Mercado De Criptomoedas: Uma Modelagem Autoregressiva Com Dados Em Painel Do Market Cap, Revista de Contabilidade e Gestão Contemporânea UFF, 2(1), 51-62,

Dzenopoljac, V,, Yaacoub, C,, Elkanj, N,, \& Bontis, N, (2017), Impact of intellectual capital on corporate performance: evidence from the Arab region, Journal of Intellectual Capital,

Edvinsson, L. (1997), Developing intellectual capital at Skandia, Long range planning, 30(3), $366-373$

Hanafi, H. (2020), Pengaruh Human Capital Terhadap Kinerja Karyawanpada Pt Bank Sumut Syariah Medan (Doctoral dissertation, Universitas Islam Negeri Sumatera Utara),

Herli, M,, \& Hafidhah, H, (2018), Intellectual Capital And Profitability Towards Firm Value: Analysis Using Quantile Regression Approach, Proceedings Universitas Pamulang, 1(1),

Indriyani, E, (2017), Pengaruh ukuran perusahaan dan profitabilitas terhadap nilai perusahaan, Akuntabilitas: Jurnal Ilmu Akuntansi, 10(2), 333-348,

Kamela, H, (2021), Liability, Market Cap Terhadap WACC, Journal of Applied Accounting and Taxation, 6(1), 115-122,

Kianto, A, Sáenz, J, \& Aramburu, N, (2017), Knowledge-based human resource management practices, intellectual capital and innovation, Journal of Business Research, 81, 11-20,

Mashali, F, A. (2018), Pengaruh Intellectual Capital Terhadap Kinerja Keuangan dan Nilai Pasar Perusahaan (Studi Empiris pada Perusahaan yang Termasuk dalam Indeks LQ45 di Bursa Efek Indonesia Tahun 2013-2016)(Doctoral dissertation, Perpustakaan Fakultas Ekonomi dan Bisnis Unpas Bandung),

Nurcahyono, O, H, \& Astutik, D, (2018), Harmonisasi Masyarakat Adat Suku Tengger (Analisis Keberadaan Modal Sosial Pada Proses Harmonisasi Pada Masayarakat Adat Suku Tengger, Desa Tosari, Pasuruan, Jawa Timur), Dialektika Masyarakat: Jurnal Sosiologi, 2(1), 1-12,

Obeidat, B, Y, Tarhini, A, Masa'deh, R, E, \& Aqqad, N, O, (2017), The impact of intellectual capital on innovation via the mediating role of knowledge management: a 
structural equation modelling approach, International Journal of Knowledge Management Studies, 8(3-4), 273-298,

Rajindra, R,, Burhanuddin, B,, Wahba, W,, Guasmin, G,, \& Febrianti, D, (2018), Effect Of Working Capital And Production Ability To Financial Performance Of UMKM, Jurnal Sinar Manajemen, 5(1), 9-23,

Sardo, F, Serrasqueiro, Z, \& Alves, H, (2018), On the relationship between intellectual capital and financial performance: A panel data analysis on SME hotels, International Journal of Hospitality Management, 75, 67-74,

Sari, L, P, (2019), Pengaruh struktur modal, profitabilitas dan ukuran perusahaan pada nilai perusahaan (Doctoral dissertation, STIE Indonesia Banjarmasin),

Seth, H, Chadha, S, \& Sharma, S, (2019), Redesigning the efficiency process analysis for working capital models, Journal of Global Operations and Strategic Sourcing,

Smriti, N, \& Das, N, (2018), The impact of intellectual capital on firm performance: a study of Indian firms listed in COSPI, Journal of Intellectual Capital,

Suwardika, I, N, A, \& Mustanda, I, K, (2017), Pengaruh leverage, ukuran perusahaan, pertumbuhan perusahaan, dan profitabilitas terhadap nilai perusahaan pada perusahaan properti, E-jurnal Manajemen, 6(3), 1248-1277,

Tulung, J, E, Saerang, I, \& Pandia, S, (2018), The influence of corporate governance on the intellectual capital disclosure: a study on Indonesian private banks, Banks and Bank Systems, 13(4),

Utomo, E, P, (2018), Internalisasi Nilai Karakter Gotong Royong Dalam Pembelajaran IPS untuk Membangun Modal Sosial Peserta Didik. Jurnal Teori Dan Praksis Pembelajaran IPS, 3. 